\title{
Attributes of Academicians' Credit Card Usage Behaviors in Malaysia
}

\author{
Chooi-Yi Wei ${ }^{1}$, Lai-Kwan Chin ${ }^{2}$, Yoke-Chin Kuah ${ }^{3}$, Mei-Si Chia ${ }^{4}$ \\ 1,2,3,4Faculty of Business and Finance, Universiti Tunku Abdul Rahman, Malaysia \\ weicy@utar.edu.my \\ DOI: https://doi.org/10.37134/jcit.vol8.8.2018
}

\begin{abstract}
In line with the advance in technology and the increasing demands for better services, the market for credit card has shown tremendous growth performance,. The genuine usage of credit card in the form of convenience has diverged to associate with overspending, irresponsibility, revolving liability and bankruptcy. This infers that the possession of credit cards has brought upon a change in consumers' usage behaviors. Thus, this study aims to determine the academicians' credit card usage behaviors in a private tertiary institution in Malaysia. The dependent variable is usage behavior and the independent variables that serve as attributes are personal attitude, spending and repayment patterns. Meanwhile, the moderating variable in this study is gender. Data obtained via questionnaire were keyed into Statistical Packages for Social Science (SPSS) version 22.0 to generate descriptive statistics such as the demographic profile of respondents and inferential analysis such as independent sample t-test, Pearson correlation and reliability test. The finding revealed that repayment patterns are the most significant attribute of academicians' credit card usage behaviors. On the other hand, there are no differences in credit card usage behavior between male and female academicians. Outcome from this study enable the government and credit card companies to relook on the requirement of granting credit card by taking into consideration of the holder's repayment ability. This enables to produce a financially healthier and educated society and also to reach to the younger generations' positively through the influence of the academicians.
\end{abstract}

Keywords: Personal attitude, spending pattern, repayment pattern, gender, credit card usage behavior

\section{INTRODUCTION}

The usage of credit card as a medium of payment has evolved tremendously since their first introduction in the United States in the early twentieth century (Ahmed, Ismail, Sohail, Tabsh, \& Alias, 2010). Ingene and Levy (1982) explained that credit card payment mechanism is a direct result of the development of a cashless society. The issuance of credit card was primarily intended to benefit both the merchant and consumer markets. Merchants lever on credit cards usage to stimulate sales and to provide facility to complete the purchases, while consumers lever on credit cards usage to expand their purchasing powers. Quoting Thomas (2000), "In modern commerce, credit cards (along with debit cards) serve as a payment device in lieu of cash or checks for millions of routine purchases as well as for many transactions that would otherwise be inconvenient, or perhaps impossible" (p. 623).

Credit cards provide an easy and convenient mode of payment to users. A credit card user is only required to present the plastic card loaded with a pre-approved amount to merchants upon transaction at the checkout counter to enjoy the benefits of the goods and services. No cash payment is required at the point of purchase. The demand for credit cards accelerated when users began to realize such benefits credit cards offer. Practically, the card issuer is advancing cash to the user upon transacting and the user is only required 
to settle the payment at a later date. Such financing facility in the form of unsecured loans provided by the issuer was far easier to be obtained by users compared with other financing means that required length and complicated process (Elangkovan \& Ahmed, 2013).

Despite the convenience payment and financing flexibility that credit cards offer, users tend to misuse the cards. At the time of purchase, they often or likely to underestimate the price of goods and portray a lack of awareness of the amount that have been charged to their cards, leading to overspending. At the time of repayment, users tend to pay only the minimum required amount, gradually accumulating larger credit balance in their credit cards. The consequence of credit card usage in Malaysia is apparent. According to Bank Negara Malaysia (BNM) (2016), total outstanding balances due from cardholders in Malaysia amounted to RM35.77 million by June 2016. However, total purchases for the period was only RM10.26 million, representing $28.7 \%$ of the total outstanding balances. This interprets that the remaining $71.3 \%$ are accumulated credit card debts from previous periods. In addition, a depressing fact revealed that the total amount of bank loan applications by individuals for the purpose of credit card payments has increased by $56.8 \%$ over a one-year period ending June 2016 to RM41,785 million from RM26,657 million (BNM, 2016). Such increase interprets that the credit card debts are rising. On contrary, users' abilities to repay the credit card debts are thinning, leading them to seek bank loans to revolve their debt as an alternative.

Ahmed et al. (2010) stated that the easy availability of financing by credit cards has led to many adverse consequences such as compulsive spending and excessive debt. This is supported by Omar, Rahim, Wel, and Alam (2014) where the authors added that users regard the plastic card as a booster to self-esteem and tend to use it to satisfy their cravings for materialism, resulting in financial distress and bankruptcy. In Malaysia, the nonperforming loans due to credit cards payments are on increasing trend. For the period of one year ending June 2016, total amount of non-performing loans due to credit cards payment default increased by $7.3 \%$ to RM483.9 million. Other relevant past studies on the impact of credit card usage on holders' attitudes had been conducted by Foscht, Maloless, Swoboda and Chia (2010), Fogel and Schneider (2011), Penman and McNeil (2008), Nga, Yong and Sellappan (2011).

The genuine usage of credit card in the form of "convenience" has been diverted to become a "necessity" and a "symbol of status". It is unfortunate that currently it connotes "overspending", "irresponsibility", "revolving liability" and "bankruptcy". This infers that the possession of credit cards has brought upon a change in consumers' usage behaviors.

Empirical studies on credit cards usage behaviors focused predominantly on college students and working adults. Limited studies were available among academicians. Cebeci and Sanli (2016) conducted a study on academicians' attitudes towards credit card usage on 158 academicians in a university in Turkey in 2015. The study found that the trust on credit card has significant and positive impact on credit card usage among the academicians, where academicians do not adjust their expenditure according to budget when they use credit cards. In addition, the study also found that the usage of credit card does not lead to overspending. The trust on credit card usage also does not cause irregular spending and excessive borrowing among the academicians.

However, the outcomes from the study of Cebeci and Sanli (2016) are unable to be generalized to other countries due to differences in legal, cultural, geographical and socio- 
economic structures between countries, industries and markets. Hence, this study tends to fulfill the research gaps by taking on the setting of academicians in a private tertiary institution in Malaysia with several attributes served as independent variables to identify either these attributes will influence their credit card usage behaviors or not.

\section{CREDIT CARD IN MALAYSIA}

Credit cards were first introduced in Malaysia in the 1970s (Tan, Ten \& Loke, 2011). Credit card ownership and usage amount in Malaysia have witnessed an upward trend (Hussin, Kassim \& Jamal, 2013; Omar et al., 2014). The number of credit cards in circulation by end June 2016 in Malaysia amounted to 9.0 million (an increase by 0.6 million cards yoy). Correspondingly, total purchases with credit cards for one year period ending June 2016 increased by RM5.8 million to RM121.04 million (BNM, 2016).

The eligibility criteria to obtain a credit card in Malaysia, only minimum annual income of RM24, 000 considered eligible for a Malaysian to obtain a credit card. On the other hand, applicants with annual earning of RM36, 000 are limited to maximum of two credit cards. In addition, according to Bank Negara Malaysia, the maximum credit limit offered to credit cardholder should be less than two times of credit cardholder's monthly income. If the outstanding credit card balance exceeds the credit cardholder maximum credit limit, they will be given a maximum period of two years to settle the outstanding credit card balance (BNM, 2011). This alternative aim is to maintain the household debts at a manageable level.

In terms of repayment, a credit card holder should repay a minimum $5 \%$ of their monthly expenses via credit card or RM50, whichever is higher. Any outstanding balance is charged a flat rate of $18 \%$ interest per annum (Tan et al., 2011). In addition, Malaysia Government imposed a RM50 service tax on principal credit card and RM25 for supplementary card and this service tax was abolished with the implementation of Goods and Services Tax (GST) on the $1^{\text {st }}$ April 2015. Thus, credit card holders were required to pay $6 \%$ of annual fees on their credit card hold. On the other hand, Credit Counselling and Debt Management Agency (AKPK) were set up by BNM in April 2006 to provide advice on debt management to those credit card holders that have doubts in handling their repayment.

There are currently twenty four credit card issuers in Malaysia, of which twentyone are banking institutions (BNM, 2015). Issuers, in an attempt to sustain competitiveness in the credit card industry and to increase card usage, are offering privileges of ownership and credit incentives for instance, free cash, cash refunds, gifts and draws to overseas holiday trips. Flexibility in payment policy such as lower financing rates and ease of conversion to personal loans at attractive rates have proliferated the usage of credit cards. Due to the credit card issuers being required to adopt fair, transparent and responsible approach in marketing, they have to provide a product disclosure sheet which disclosure all of the key information on the card's features, fees and credit cardholder obligation to facilities consumers in decision making. Furthermore, credit card issuers are not allowed to increase the credit limit and to offer a credit advance in the form of cheque payable to their credit cardholders unless it is requested by them (BNM, 2011). 
Researches have been conducted on credit card usage behaviors in the past in Malaysia (Ramayah, Nasser, Aizzat, \& Lim, 2002; Ahmed et al., 2010; Nga et al., 2011; Jusoh \& Lin, 2012; Rasiah \& Masuod, 2013). However, the emphasis in this study has been on credit card usage behaviors among academicians in a private tertiary institution.

The attitudes and leadership skills of academicians have direct influence to the younger generations. In this respect, academician is encouraged to portray positive attitudes and leadership skills in their teaching. According to Nawi, Redzuan and Nawi (2013), self- management and social awareness are closely associated to development of positive attitudes and leadership traits. This inferred that academicians should possess high level of self- management and social awareness. Such positive attributes contribute to academicians' ability to exercise discipline in their actions and have high awareness on consequences to their actions.

This study aims to identify the most significant attribute of academicians' credit card usage behavior in a private tertiary institution in Malaysia. The major research questions addressed in this study are:

(a) What is the most significant attribute of academicians' credit card usage behavior in a private tertiary institution?

(b) Is there any significant difference in the attributes of academicians' credit card usage behavior in a private tertiary institution based on gender?

This study includes a brief literature review on the attributes that influence the usage behaviors of credit card holders. Next, the methodology is explained, followed by discussion on the research finding including limitation and recommendation for future researches following with implication and conclusion.

\section{REVIEW OF LITERATURE}

\section{Credit Card Usage based on Personal Attitudes}

Personal attitude plays an important role in portraying how cardholders use the plastic card, for instance the usage frequency, choice of usage and intentions to purchase. Numerous studies have been carried out to determine the effects of attitudes on credit card usage (Klein, 1999; Penman \& McNeil, 2008; Ahmed et al., 2010; Foscht et al., 2010 \& Nga et al., 2011).

Klein (1999) stated that the ownership of a credit card has indirectly presented users with opportunities to new and exciting experiences, which previously were unavailable to them. Such opportunities lead to an increase in the adoption and usage of credit cards.

On the other hand, Penman and McNeil (2008) applied qualitative approach in their data collection method. A two -stage design is employed, consisting of focus groups on first and second-year university students followed by in-depth interviews with these focus groups. The finding reveals that the credit cardholders' usage behavior is influenced by factors such as lifestyle, upbringing and family structure. A person attitude was formed since he or she was young and it will affect their usage behaviors once they grow up and enter into the social. This attitude remains and indirectly influences the youth's perception 
of monetary value, level of materialism and self-esteem. In addition, the study also affirmed that card users tend to purchase on impulse to achieve a degree of self-image (an image they wish to portray). It further stated that repeated experiences of low self-esteem leads to non-essential purchases, leading to increase in use of credit card.

Contrary to earlier studies, Ahmed et al. (2010) found that self-esteem does not affect usage attitude in Malaysia. The authors reasoned that this is due to the fact that credit card is no longer considered a symbol of status that enhances self-esteem. In addition, Nga et al. (2011) investigated the relationship between image consciousness, materialism and compulsive spending and the intention to use credit card among youths in Malaysia. An anonymous survey questionnaire was administered to 191 Business and Management program's students from a private tertiary institution in Subang Jaya, Malaysia. The finding revealed that the materialism is not significantly related to credit card usage.

From the study conducted in Austria, Foscht et al. (2010) explored the linkage between choices of payment modes and customer satisfaction. Their study indicated that consumer's preference is dependent on individual personal attitudes, and that credit cards were more preferable than debit cards in terms of customer satisfaction.

In Turkey, Cebeci and Sanli (2016) conducted a study on academicians' attitudes towards credit card usage in a university. The author employed primary data with questionnaire on 158 academicians from April to June 2015 and analyzed them with the approach of Explanatory Factor Analysis (EFA) and Structural Equation Modeling (SEM). The study found that trust on credit card, information on credit card, rationale spending and credit card expenditures have significant impact on credit card usage among the academicians of the university. Among the four factors, trust on credit card has the highest positive impact on credit card usage.

In this study, one of the concerned areas to be investigated included personal attitude of academicians toward their behavior of credit card usage. Thus, based on the arguments above and past evidences, the first hypothesis of this study is as below:

Hypothesis 1: There is a significant relationship between personal attitude and academician's credit card usage.

\section{Credit card Usage based on Spending Patterns}

The multi-functional aspects of credit cards, such as the ability to purchase beyond affordability, the ability to maintain a degree of anonymity in certain purchases and leveraging on revolving provisions has led to an increase in credit card spending (Klein 1999). Foscht et al. (2010) suggested that the introduction of different modes of payment (including credit cards) is one of the factors contributing towards the increase in consumer credit. Chan (1997), based on his study of the differences between "active" and "inactive" cardholders in Hong Kong, found that active cardholders display favorable attitudes towards "larger credit limit" than the inactive cardholders. This study also showed that credit limit plays an important role in credit card usage and spending patterns. A low credit limit, in effect could restrain cardholders from spending. This implies that by increasing credit limits, cardholders tend to be motivated and encouraged to spend more. It showed that an increase in credit limits leads to direct and significant escalation in credit card debts. 
Ramayah et al. (2002) examined the attributes affecting the credit card usage between inactive and active cardholders in Malaysia. The study showed, from demographic perspective, credit card usage level in generally, was higher among credit cardholders with age of 30 years and above, with monthly income more than RM4, 000, white collar occupation and owned 3 cards or more. People tend to spend more when they are in financially stable and owned several credit cards. The study also showed that usage is higher when there is effective handling of cardholder's complaint, good bank image, lower annual fee, large credit limit, wide acceptance, and long interest free repayment period. Similar results are produced by Themba and Tumedi (2012) in Botswana.

Omar et al. (2014) in their study focusing on the factors influencing credit card spending among working adults in Malaysia, reported that credit card spending positively related to compulsive buying but negatively related to self- esteem. The compulsive buying suggested that Malaysian consumers had tendency to spend lavishly or make extra purchase when they use credit cards. The authors further explained the increase in spending due to low self-esteem indicates the desire to attain social status through material possession.

Designated professions such as academicians in universities have greater access to revolving credit facilities as credit limits are normally set by income levels compared to undesignated professions which have very low or limited access to financing options (Dewri, Islam \& Saha, 2016). In this study, based on the arguments above and past evidences, the spending patterns of academicians in a university would be analyzed. Thus, the second hypothesis of this study is as below:

Hypothesis 2: There is a significant relationship between spending patterns and academician's credit card usage.

\section{Credit Card Usage based on Repayment Patterns}

Information technology also plays an important role in changing the repayment habits. The younger generation prefers to use modern technology to pay their credit card outstanding balance (Dewri, Islam \& Saha, 2016). The study also showed that younger users in Bangladesh have greater tendency to repay their credit cards outstanding balance partially compared to senior citizens. This implied that the trend of revolving credit has become apparent. According to Tamara and Javier (2004), the competition among credit card companies are increasing. In order to attract and enhance and to attract customers, the credit card companies lower their minimum payment requirements from 5 percent to 2 or 3 percent of the outstanding balance. As a result, credit card owners who pay the minimum payment stipulated would carry more outstanding balances. It was noticed that credit card repayments were closely aligned with the outstanding balance and the user's willingness to spend on a credit basis. In this study, the repayment patterns among academicians in a different area of expertise would be examined. Thus, the third hypothesis of this study is as below:

Hypothesis 3: There is a significant relationship between repayment patterns and academicians' credit card usage. 


\section{Credit card based on Gender}

Numerous studies have been undertaken in the past to differentiate usage behavior based on gender. Elangkovan and Ahmed (2013) proved that women tend to overspend on unexpected and unnecessary expenses compared to men in Malaysia. Yet, this finding contradicted with the outcome by Hussin et al. (2013). Applying the convenient sampling method and questionnaire survey was distributed to 350 credit card holders in the Klang Valley, Malaysia. The findings revealed that there were no significant differences between male and female customers with regards to credit card usage.

However, in Turkey, Cankaya, Ucal and O'neil (2011) found that women understand better compared to male on the consequences of their credit card usage since they are keen to make full payment and on time rather than servicing minimum payment. Women spent mainly on food, clothing, cosmetics and household goods using credit cards. Similar results were obtained from Limbu, Huhmann and Xu (2012). The authors reported that women were far better than men in managing monthly outstanding balances, implying that women are more cautious in credit card usages and finances. They reasoned that women have lower tendency to take risks, thus they disassociate themselves from excessive credit card debts.

On the other hand, similar results were obtained from previous studies by Themba and Tumedi (2012) revealed that youth and female have negative attitude towards debt. The gender based attitudes differ due to differences in culture, religious beliefs, earning capacity and credit availability (Dewri et al., 2016). Thus, understanding gender differences in credit card usage has significant implications. Therefore, this study included gender as a moderating variable to differ the relationship of personal attitude, spending pattern and repayment pattern toward credit card usage behaviors among male and female academician in UTAR, Kampar campus. Thus, the fourth hypothesis of this study is as below:

Hypothesis 4: There are differences between male and female academicians with respect to credit card usage behaviors.

\section{THEORY OF PLANNED BEHAVIORS (1991)}

The theoretical framework as shown in Figure 1 was developed based on the Theory of Planned Behaviors by Ajzen (1991). This theory was developed to predict a person's behavior through their intentions to improve on predictive power of the Theory of Reasoned Action by including perceived behavior control. This theory applied to studies of the relations among beliefs, attitudes, behavioral intentions and behavior in various filed such as advertising, public relations, advertising campaigns and healthcare. 


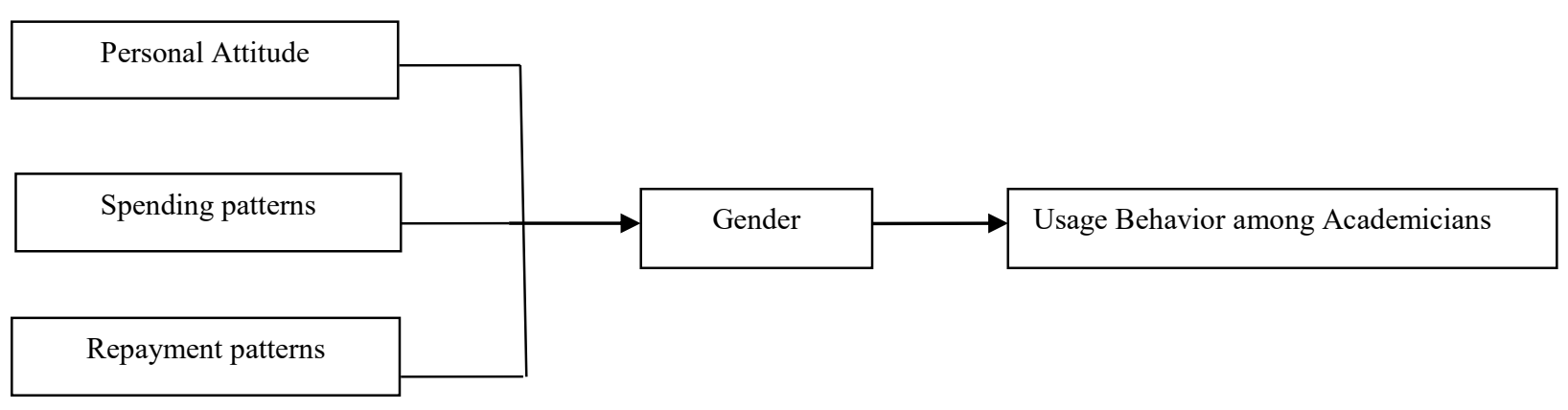

Figure 1: Theoretical Framework

Source: Modified from Ajzen (1991)

\section{METHODOLOGY}

This exploratory study was taken place in Universiti Tunku Abdul Rahman, Kampar Campus, Perak, Malaysia (UTAR). The main purpose of this study is to determine the attributes of UTAR academicians' regardless their gender, age, education qualification, equip with or without financial literacy toward credit card usage behaviors.

\section{Population and Sample}

In this study, the population consists of 590 academicians from 6 different faculties, namely Faculty of Engineering and Green Technology (FEGT), Faculty of Information Communication Technology (FICT), Faculty of Arts and Social Science (FAS), Faculty of Science (FS), Faculty of Business and Finance (FBF) and Institute of Chinese Studies (ICS). Stratified sampling technique was applied to determine the ratio of sample size to be obtained in each faculty. Relevant ratio via stratified sampling technique applied to obtain data from each faculty in order to avoid bias of respondent in this study. According to Krejcie and Morgan (1970), the approximate sample size would be 234 samples for a population of 600 academicians. Thus, 250 questionnaires had been distributed to the academic staffs across faculty according to the ratio of sample obtained via stratified sampling technique. Finally, completed questionnaires of 229 sets were keyed into Statistical Package for Social Science (SPSS) version 22 to generate the descriptive statistics such as demographic profiles of respondents' and the inferential analysis namely independent samples t-test, Pearson correlation and reliability test and mean scoring analysis.

\section{Pilot Test}

A set of pilot questionnaires was given to 30 academicians selected on a random sampling basis in the same institution prior to the actual study to determine the reliability of the items in the questionnaire. A reliability test was conducted and it indicated a Cronbach alpha value of 0.826 which proved that all items are reliable for the actual study. The respondents involved in the pilot test were not selected as participants for the actual study. 


\section{Data Collection}

In order to obtain the data, a set of questionnaire was developed by researchers based on past studies and distributed to academicians across the faculties. The questionnaire consists of 2 sections. Section A was developed to gather the respondent's demographic information. Section B comprised 10 items for each construct (personal attitude, spending and repayment patterns) and totaled 30 items as summarized in Table 1 below.

Table 1: Number of items per construct

\begin{tabular}{ccc}
\hline No & Constructs & Number of items \\
\hline 1. & Personal Attitude & 10 \\
2. & Spending patterns & 10 \\
3. & Repayment patterns & 10 \\
\hline
\end{tabular}

\section{RESULT}

\section{Descriptive Analysis}

As shown in Table 2, the majority of samples were from the Faculty of Business and Finance (FBF) (41.9\%). There were 127 males (55.5\%) and 102 females (44.5\%) in the sample. A majority of the respondents spent around RM501 to RM1000 on goods and services on a monthly basis using credit card.

Table 2: Demographic profile of respondents

\begin{tabular}{cccc}
\hline & & Frequency & Percentage (\%) \\
\hline \multirow{2}{*}{ Gender } & Male & 127 & 55.5 \\
& Female & 102 & 44.5 \\
Faculty & FEGT & 30 & 13.1 \\
& FICT & 15 & 6.6 \\
& FAS & 35 & 15.3 \\
Average usage via credit card (monthly) & FS & 44 & 19.2 \\
& FBF & 96 & 31.9 \\
& ICS & 9 & 3.9 \\
& RM100 - RM500 & 71 & 38.9 \\
& RM501 - RM1000 & 89 & 13.1 \\
\hline
\end{tabular}

\section{Correlation Test}

Table 3 shows the relationship of each independent variable with credit card usage behaviors among academicians. A two-tailed test at 0.05 significance level indicated positive relationships between each independent variable (attitude, spending and payment patterns) and credit card usage behaviors among academicians. The significant results from personal attitude, spending and repayment patterns could be generalized to the total population. 
Table 3: Pearson Correlation results

\begin{tabular}{lcc}
\hline Variable & Pearson Correlation (r) & Significant \\
\hline Personal attitude & 0.364 & $.001^{*}$ \\
Spending patterns & 0.268 & $.000^{*}$ \\
Repayment patterns & 0.255 & $.000^{*}$ \\
\hline
\end{tabular}

Note: * Correlation is significant at the .05 level (2-tailed)

\section{Significant Attributes of Academicians' Credit Card Usage Behavior}

As shown in Table 4, analysis of mean of 3.5432 and standard deviation of 0.3932 revealed that repayment patterns serve as the most significant attribute of academicians' credit card usage behaviors.

Table 4: Means and standard deviation for each construct

\begin{tabular}{lccc}
\hline Variable & N & Mean & Standard deviation \\
\hline Personal attitude & 229 & 3.2961 & .3538 \\
Spending patterns & 229 & 3.0716 & .4120 \\
Repayment patterns & 229 & 3.5432 & .3932 \\
\hline
\end{tabular}

\section{Attributes of Academicians' Credit Card Usage Behaviors based on Gender}

In this study, independent sample T-test was employed to determine the differences in credit card's usage behaviors between male and female academicians in UTAR. Table 5 shows that at the significance level, p-value is more than .05 for all the independent variables. Thus, null hypothesis is accepted for all the constructs. This proves that there are no significant differences in personal attitude, spending and repayment patterns between male and female UTAR academicians' credit card's usage behaviors. This result is consistent with previous study by Hussin et al. (2013) found out that there is no significant difference between male and female customers with regards to credit card usage. However, this research finding contradicted with the results obtained by Cankaya et al. (2011) which stated that women understand better compared to male on the consequences of their credit card usage since they are keen to make full payment and on time rather than servicing minimum payment.

Table 5: T-test analysis to determine the differences based on gender

\begin{tabular}{|c|c|c|c|c|c|c|}
\hline Variable & Gender & $\mathbf{N}$ & Mean & $\begin{array}{l}\text { Standard } \\
\text { deviation }\end{array}$ & t- value & Sig. \\
\hline $\begin{array}{l}\text { Personal } \\
\text { attitude }\end{array}$ & $\begin{array}{l}\text { Male } \\
\text { Female }\end{array}$ & $\begin{array}{l}127 \\
102\end{array}$ & $\begin{array}{l}3.2622 \\
3.3382\end{array}$ & $\begin{array}{l}.3464 \\
.3602\end{array}$ & -1.622 & .106 \\
\hline $\begin{array}{l}\text { Spending } \\
\text { patterns }\end{array}$ & $\begin{array}{l}\text { Male } \\
\text { Female }\end{array}$ & $\begin{array}{l}127 \\
102\end{array}$ & $\begin{array}{l}3.0465 \\
3.1029\end{array}$ & $\begin{array}{l}.4071 \\
.4180\end{array}$ & -1.031 & .304 \\
\hline $\begin{array}{l}\text { Repayment } \\
\text { Patterns }\end{array}$ & $\begin{array}{l}\text { Male } \\
\text { Female }\end{array}$ & $\begin{array}{l}127 \\
102\end{array}$ & $\begin{array}{l}3.5748 \\
3.5039\end{array}$ & $\begin{array}{l}.4261 \\
.3458\end{array}$ & 1.358 & .176 \\
\hline
\end{tabular}




\section{DISCUSSION}

The research results revealed that all the independent variables have a direct relationship with the dependent variable. Accordingly, the dimensions of personal attitudes, spending and repayment patterns affect the manner in which academicians use their credit cards. These results are in line with findings of previous studies (Penman \& McNeil, 2008; Nga et al., 2011; Ahmed et al., 2010).

The study of personal attitudes on credit card usage is profound. The contributing factors include but are not limited to individual's upbringing, social influences and level of self-satisfaction (Penman \& McNeil, 2008). This study shows that academicians' attitude influences the usage of credit cards. Academicians with their higher educational qualifications and stable financial backgrounds are generally able to practice selfawareness and discipline with regards to usage of credit cards. No differences were noted between male and female academicians on credit card usage behaviors

Although the study offers insights into credit card usage behaviors among academicians, it has its limitations. The first limitation is the nature of the sample. A random sample could have caused low response rate and possible result bias. Secondly, the sample was collected from only one university. Thus this study might not be truly representative of the actual nature of credit card usage behaviors of academicians, in comparison with academicians in other universities. Thirdly, the respondents' profiling shows a predominantly Chinese ethnic composition (68 percent of total respondents) and the majority of the respondents (71 percent) hold a Master's degree.

\section{IMPLICATIONS}

The above findings should provide some implications to the government and credit card companies. The stakeholders are interested in understanding spending and repayment behaviors on academician.

On top of that, the finding from this study enables government to understand the correlation between credit usage behavior and bankruptcy rates among credit card holders. Government is recommended to carry out the campaign to educate young consumer on the usage of credit card and tighten the regulation for new credit card applicants.

On the other hands, outcome from this study also able to imply the credit card companies to relook on the requirement of granting credit card by taking into consideration of the holder's repayment ability. This enables to produce a financially healthier and educated society and also to reach to the younger generations' positively through the influence of the academicians. The results would also assist cardholders to fathom the importance of their attitudes towards money, credit and debt.

\section{CONCLUSION}

As conclusion, educators could play a role through advice and educate the younger generation to identify their personality traits and focus on decisions making especially involving financial matter and credit in this highly globalized society. Future researches 
might wish to draw opportunities from this study. In general, a nationwide study should consider a wider range of respondents from private and public higher learning institutions. In addition, future researchers could focus on other general attributes of credit card usage behaviors among academicians, for instance, attitudes towards credit card debts and payment methods, inducement factors for adoption and choice of credit cards.

\section{REFERENCES}

Ahmed, Z. U., Ismail, I., Sohail, M. S., Tabsh, I., \& Alias, H. (2010). Malaysia consumers' credit card usage behavior. Asia Pacific Journal of Marketing and Logistic, 22(4), 528-544.

Bank Negara Malaysia. (2011). Annual Report. Kuala Lumpur:Central Bank of Malaysia.

Bank Negara Malaysia. (2016). BNM Catalogue - Monthly Statistical Bulletin June 2016. http://www.bnm.gov.my/index.php?ch=en_publication_catalogue\&pg=en_publication_msb\&mth=6\&yr= 2016\&lang=en. Accessed August 2016.

Bank Negara Malaysia. (2015). BNM Payment Systems - List of Regulatees. http://www.bnm.gov.my/?ch=ps\&pg=ps_regulatees\#Credit. Accessed August 2016.

Cankaya, S., Ucal, M., \& O'neil, M. L. (2011). Effects of gender on credit card usage among university students in Turkey. African Journal of Business Management, 5(22), 9023-9030.

Cebeci, I., \& Sanli, T. (2016). A research study on the Attitude towards Credit Card Usage of the Academic Staff at Giresun University in Turkey. Global Journal for Research Analysis, 5(4), 117-119.

Chan, R. (1997). Demographic and attitudinal differences between active and inactive credit cardholders - the case of Hong Kong. International Journal of Bank Marketing, 15(4), 117-25.

Dewri, L. V., Islam, M.R., \& Saha, N.K. (2016). Behavioral Analysis of Credit Card Users in a Developing Country: A Case of Bangladesh. International Journal of Business and Management, 11(4), 299.

Elangkovan, K., \& Ahmed, R. A. L. (2013). Bankruptcy: A Natural Phenomena Being Attacked On Malaysians. International Journal of Humanities and Management Sciences, 1(1), 74-76.

Fogel, J., \& Schneider, M. (2011). Credit card use: Disposable income and employment status. Young Consumers 12(1), 5-14.

Foscht, T., Maloless, C., Swoboda, B., \& Chia, S. L. (2010). Debit and credit card usage and satisfaction: Who uses which and why - Evidence from Austria. International Journal of Bank Marketing, 28(2), 150-165.

Hussin, S. R., Kassim, S. \& Jamal, N. (2013). Credit card holders in Malaysia: Customer Characteristics and credit card usage. International Journal of Economics and Management, 7(1), 108-122.

Ingene, C., \& Levy, M. (1982). Cash discounts to retail consumers: An alternative to credit card sales. The Journal of Marketing, 92-103.

Jusoh, Z., \& Lin, Y. L. (2012). Personal financial knowledge and attitude towards credit card practices among working adults in Malaysia. International Journal of Business and Social Science, 3(7), 176-185.

Klein, L. (1999). It's in the cards: consumer credit and the American experience. Greenwood Publishing Group.

Krejcie, R. V., \& Morgan, D. W. (1970). Determining sample size for research activities. Educational and Psychological Measurement, 30, 607-610.

Limbu, Y. B., Huhmann, B. A., \& Xu, B. (2012). Are college students at greater risk of credit card abuse? Age, gender, materialism and parental influence on consumer response to credit cards. Journal of Financial Services Marketing, 17(2), 148-162.

Nawi, N.H.M., Redzuan, M., \& Nawi, N.H.M. (2013). The effects of Relationship Management, SelfManagement and Social Awareness Sub-scales on Transformational Leadership Behaviour among Educational Leaders. Akademika, 83(2\&3), 3-11.

Nga, J. K. H., Yong, L. H. L., \& Sellappan, R. (2011). The influence of image consciousness, materialism and compulsive spending on credit card use intentions among youth. Young Consumers, 12(3), 243-53.

Omar, N. A., Rahim, R. A., Wel, C. A. C. \& Alam, S. S. (2014). Compulsive buying and credit card misuse among credit card holders: The roles of self-esteem, materialism, impulsive buying and budget constraint. Intangible Capital, 10(1), 52-74.

Penman, S., \& McNeil, L. S. (2008). Spending their way to adulthood: consumption outside the nest. Young Consumers, 9(3), 155-69.

Ramayah, T., Nasser, N., Aizzat, M., \& Lim, H. C. (2002). Cardholders' attitude and bank credit card usage in Malaysia: an exploratory study. Asian Academy of Management Journal, 7(1), 75-102. 
Rasiah, D., \& Masuod, S. (2013). The flexible Alternative Consumer Financing in Malaysia, Credit Cards. Journal of Social and Development Sciences, 4(3), 147-151.

Tamara, D., \& Javier, S. (2004).Generation Broke: The Growth Debt among Young Americans“. Retrieved from http://www.demos.org/pubs/Generation_Broke.pdf. Accessed 10 January 2012.

Tan, A. K., Ten, S. T., \& Loke, T. J. (2011). Credit card holders, convenience users and revolvers: A tobit model with binary selection and ordinal treatment. Journal of Applied Economics, 14(2), 225-255.

Themba, G., \& Tumedi, C. B. (2012). Credit card ownership and usage behavior in Botswana. International Journal of Business Administration, 3(6), 60-71.

Ajzen, I. (1991). The Theory of Planned Behaviour. Organizational Behavior and Human Decision Processes, 50, 179-211, Retrieved from http://www.valuebasedmanagement.net/methods_ajzen_theory_planned_behavior.html. Accessed October 202015.

Thomas, A. (2000). Credit cards: use and consumer attitudes. Federal Reserve Bulletin, 623-634. 